\title{
Metallic Nanoparticles-Friends or Foes in the Battle against Antibiotic-Resistant Bacteria?
}

\author{
Francisco Amaro * (D), Álvaro Morón, Silvia Díaz, Ana Martín-González and Juan Carlos Gutiérrez (D) \\ Department of Genetics, Physiology and Microbiology, Faculty of Biology, Complutense University of Madrid, \\ 28040 Madrid, Spain; alvmoron@ucm.es (Á.M.); silviadi@bio.ucm.es (S.D.); anamarti@bio.ucm.es (A.M.-G.); \\ juancar@bio.ucm.es (J.C.G.) \\ * Correspondence: famaroto@ucm.es
}

Citation: Amaro, F.; Morón, Á.; Díaz, S.; Martín-González, A.; Gutiérrez,

J.C. Metallic Nanoparticles-Friends or Foes in the Battle against Antibiotic-Resistant Bacteria?. Microorganisms 2021, 9, 364. https://doi.org/10.3390/ microorganisms 9020364

Academic Editor: Carlo Viti

Received: 27 January 2021

Accepted: 10 February 2021

Published: 12 February 2021

Publisher's Note: MDPI stays neutral with regard to jurisdictional claims in published maps and institutional affiliations.

Copyright: (c) 2021 by the authors. Licensee MDPI, Basel, Switzerland. This article is an open access article distributed under the terms and conditions of the Creative Commons Attribution (CC BY) license (https:// creativecommons.org/licenses/by/ $4.0 /)$.

\begin{abstract}
The rapid spread of antibiotic resistances among bacteria demands novel strategies for infection control, and metallic nanoparticles appear as promising tools because of their unique size and tunable properties that allow their antibacterial effects to be maximized. Furthermore, their diverse mechanisms of action towards multiple cell components have suggested that bacteria could not easily develop resistance against nanoparticles. However, research published over the last decade has proven that bacteria can indeed evolve stable resistance mechanisms upon continuous exposure to metallic nanoparticles. In this review, we summarize the currently known individual and collective strategies employed by bacteria to cope with metallic nanoparticles. Importantly, we also discuss the adverse side effects that bacterial exposure to nanoparticles may have on antibiotic resistance dissemination and that might constitute a challenge for the implementation of nanoparticles as antibacterial agents. Overall, studies discussed in this review point out that careful management of these very promising antimicrobials is necessary to preserve their efficacy for infection control.
\end{abstract}

Keywords: nanoparticles; heavy metals; resistance; antibiotic resistance; oxidative stress

\section{Introduction}

Multi-drug-resistant bacteria have become one of the most serious threats to public health worldwide [1]. The abuse and misuse of antibiotics have fostered the emergence and transference of resistance mechanisms among bacteria, compromising the therapeutic potential of antibiotics [2]. Among the different strategies that bacteria have evolved to withstand antimicrobial drugs [3], one is their ability to form the so-called biofilms. Bacteria can attach to a surface and grow as a biofilm community where cells aggregate together and surround themselves with a self-produced extracellular matrix that protects them from antibiotics and adverse environmental conditions. Indeed, biofilm-embedded bacteria are up to 100-1000 times more resistant to antibiotics than free-floating planktonic cells [4]. Biofilms can form on any surface, including indwelling medical devices such as catheters or artificial hips, leading to chronic infections that cannot be eradicated with antibiotics.

The rapid spread of antibiotic resistances and the rising prevalence of biofilm-associated infections demand novel strategies to address this challenge, and research has turned to nanomaterials [5,6]. Among them, metallic nanoparticles (NPs) have attracted a great deal of interest because of their special properties such as high reactivity and multiple targets on microbial cells. With many potential applications, some metal-based NPs are already being applied in numerous medical and consumer products, including medical devices, textiles, and cosmetics [5,7]. Moreover, it has been reported that NPs conjugated with antibiotics show synergistic effects against bacteria $[5,8]$. Therefore, metallic NPs could offer an effective solution for infection control by incorporating them on the contact surfaces of medical devices, textiles, food packages, and membrane filters employed in water treatment $[5,9,10]$, or by being applied topically to treat skin and wound infections [11]. 
Because NPs display multiple antibacterial mechanisms, it has been thought that bacteria are unlikely to develop resistance against these nanomaterials. However, recent studies have shown that bacteria can in fact tolerate increasing concentrations of copper and silver NPs [12-15]. Hence, concerns are rising about whether bacteria may develop resistance towards the widely commercialized NP-based antimicrobial materials. While the unique and promising properties of NPs to target bacteria have been covered previously in excellent reviews $[5,6,8,9,11]$, as a novel aspect we highlighted here studies that demonstrated risks associated with bacterial exposure to metallic NPs that may constitute a challenge for their implementation as antibacterial agents. We first describe the experimentally demonstrated mechanisms through which bacteria can gain resistance towards metallic NPs and how that could be overcome. Next, we discuss the different ways by which NPs may favor dissemination of antibiotic-resistant genes among bacteria. Up-to-date research studies in the field were retrieved from Pubmed, SciFinder, and Web of Science databases. The available data point out that careful management of these very promising antimicrobials and further studies addressing how NPs co-select for metal and antibiotic resistance are required.

\section{Antibacterial Mechanisms of Metallic Nanoparticles}

Metallic NPs consist of either metals or metal oxides. Metals such as silver and copper have been recognized for their antimicrobial effects since ancient times [16]. Furthermore, the unique properties of NPs make them promising candidates with high antibacterial activity. For instance, the large surface-to-volume ratio of NPs increases the contact area with bacteria and allows their functionalization with ligands that favor interactions with target bacteria [17]. Although most NP toxicity is attributed to the released metal ions, the antibacterial effect of a NP is highly dependent on its physicochemical characteristics such as size, surface, and charge [18,19]. Importantly, these features can be engineered to maximize bacteria-NP interactions, biofilm penetration, and NP bactericidal efficacy. NP size is a key factor as it determines whether NPs penetrate into bacterial cells and biofilms, thus increasing their toxicity [20]. Smaller particle size (2-10 nm) generally correlates with greater antibacterial effects among NPs with the same metal composition, because of high surface area contact with bacterial cells [21-24]. Further, NPs smaller than $10 \mathrm{~nm}$ in diameter can pass through porins in bacterial membranes, thus exhibiting higher toxicity than larger NPs [25]. NPs smaller than $350 \mathrm{~nm}$ have been shown to penetrate through pores within biofilms [20]. Furthermore, NPs have surface charge-dependent toxicity; thus, the more positively charged the NP surface, the more toxic the NP is [6]. The surface charge of NPs determines their interaction with the bacterial surface and biofilms. Indeed, positively charged NPs generally possess better biofilm penetration [26]. In addition, Metch and coworkers recently demonstrated that NP morphology and surface coating influence toxicity and govern NP's effects on microbial communities [27]. The interface between bacteria and NPs is characterized by electrostatic and hydrophobic interactions. Hence, positively charged and hydrophobic moieties on the NP surface can enhance antibacterial activity [5]. Finally, contact with bacterial components can be influenced by NP shape. In fact, it has been shown that truncated triangular Ag-NPs display greater bactericidal activity than spherical and rod-shaped Ag-NPs [28]. This difference has been attributed to the number of NP facets interacting with the bacterial components. Triangular NPs have more facets than spherical or rod-shaped NPs, and thus cause more cellular damage [5]. In addition, it has been shown that pointed and sharp NPs can pierce bacterial cell membranes, causing cytosolic leakage [28].

Metallic NPs have proved antimicrobial activity against different microorganisms, including a broad spectrum of both Gram-negative and Gram-positive bacteria [8,17,29-38]. Despite the large set of experimental data on NP toxic effect, their mechanisms of action are still under debate [39]. Globally, the antibacterial action of NPs is attributed to several causes: (i) cell membrane damage and disruption of membrane potential, (ii) generation of reactive oxygen species (ROS) such as hydroxyl radicals $\left(\mathrm{OH}^{-}\right)$and superoxides $\left(\mathrm{O}_{2}{ }^{-}\right)$, and (iii) damage to DNA and proteins and inhibition of enzymatic activities [5] (Figure 1A). 
The negatively charged bacterial cell wall attracts positively charged NPs due to electrostatic interactions. After adhesion onto the bacterial surface, NPs release ions that enter the cell or bind to and destabilize the cell membrane, affecting its permeability and transport activity. ROS generated by NPs oxidize lipids contributing to membrane damage as well [39]. This allows ions and NPs to reach the cytoplasm, where they can induce ROS production, leading to oxidative stress [29,40-43]. Moreover, ions released from Ag-NPs and $\mathrm{Cu}-\mathrm{NPs}$ can directly interact with DNA and iron-cysteine clusters present in proteins disrupting their structure and activity $[41,44]$. Thus, eventually, the extensive damage to a wide spectrum of cell components causes bacterial death.
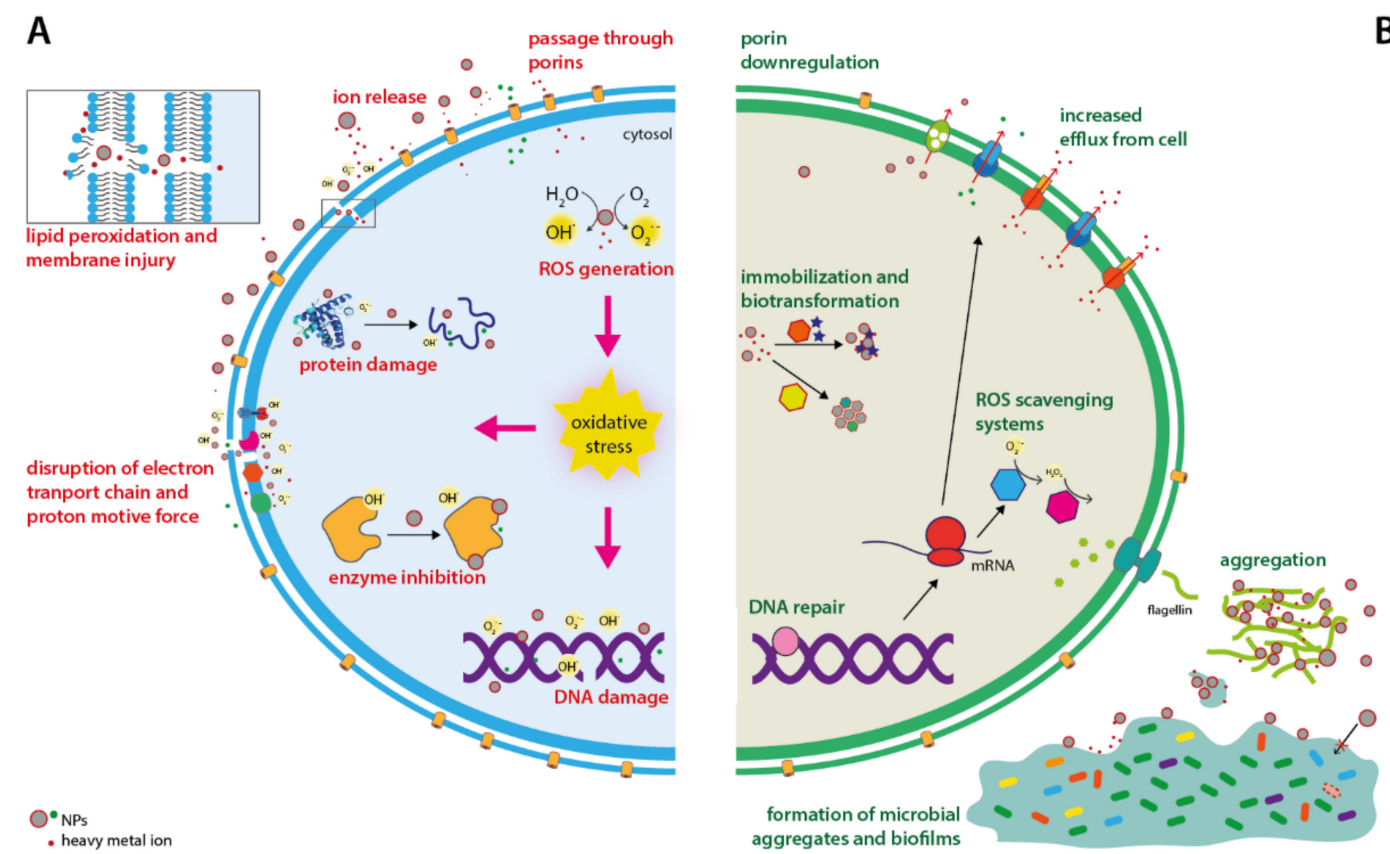

Figure 1. Antimicrobial activities of metallic nanoparticles (A) and mechanisms of resistance described in bacteria (B). Nanoparticles can damage cell lipids, proteins, and DNA by direct binding or by inducing oxidative stress. To cope with metallic nanoparticles bacteria can reduce metal entry through porin downregulation, overexpressing metal efflux systems, and upregulate antioxidant defenses and DNA repair systems. Furthermore, some bacterial species have evolved mechanisms to modify and immobilize nanoparticles in aggregates with lower toxicity by using enzymatic systems or by secreting polymeric materials that trap nanoparticles in the extracellular environment.

\section{Bacterial Resistance Mechanisms towards Metallic Nanoparticles}

Because NPs do not need to penetrate into the cell to exert their bactericidal effects, it was proposed that they might overcome antibiotic resistance mechanisms [41]. Furthermore, the non-specific mode of action of NPs toward multiple cellular components suggested that development of resistance is less likely to occur, as bacteria would have to acquire multiple mutations $[41,43,45]$. In line with this hypothesis, Valentin and coworkers recently showed that Staphylococcus aureus more readily developed resistance to ciprofloxacin than to 2-nm Ag-NPs [14]. However, over the last years, a growing body of research has evidenced that bacteria can indeed evolve defense strategies to cope with metallic NPs (Figure 1B). Bacteria with increased resistance to $\mathrm{Ag}^{+}$ions and $\mathrm{Ag}-\mathrm{NPs}$ have been repeatedly isolated from clinical and non-clinical environments [46-48]. More importantly, different researchers have recently proven that resistance to Ag-NPs or Cu-NPs can be quickly induced in vitro in both laboratory and clinical strains after repeated exposure to sublethal doses of NPs. These studies included the ubiquitous Shewanella oneidensis and several Bacillus species, as well as opportunistic pathogens such as Escherichia coli, Pseudomonas aeruginosa, or S. aureus [13,15,49-52]. Of particular concern is the fact that rapid Ag-NP resistance development has also been observed in antibiotic-resistant strains $[50,53]$. 
Lastly, the ability of bacteria to withstand increasing concentrations of complex metallic NPs (e.g., nickel manganese cobalt oxide NPs) has also been demonstrated in conditions that mimic chronic environmental exposure [49]. Therefore, it is becoming apparent that continuous exposure to sublethal/subinhibitory doses of NPs can favor bacterial resistance. Given the great potential of metallic NPs for infection control, it is urgent to understand how resistance arises; the molecular basis behind it, and to what extent resistance is stable or can be overcome.

The studies published over the last years have shown that bacteria use both individual and collective defense strategies to protect themselves from NPs. While individual cells use their genetically encoded defense mechanisms to withstand NP toxicity, bacteria may also benefit from the additional protection conferred by collective responses, such as the formation of microbial aggregates and biofilms, or the production of substances that immobilize or modify NPs $[13,54,55]$.

Individual strategies mainly involve decreased NP uptake or adsorption, enhanced efflux [56], and detoxification of NP-generated ROS [51,57] (Figure 1B). Cation-selective porins allow for the passage of smaller NPs and NP-released ions through the outer membrane in Gram-negative bacteria [58]. Thus, porin downregulation restricts the access routes of metal ions and renders bacteria less susceptible to NP action. Indeed, loss of porins and overexpression of efflux systems are frequently observed adaptations in Agresistant clinical strains isolated from burn wards [46]. Accordingly, different studies have reported downregulation of genes encoding porins in E. coli and P. aeruginosa exposed to Ag-NPs and Cu-NPs, respectively [12,59]. More importantly, mutations that result in OmpC or OmpF porin deficiency have been associated with increased resistance to Ag-NPs in E. coli compared to wild-type strains [60].

In addition to restricting entrance, bacteria use a wide variety of efflux systems to extrude metal ions outside the cell [12,51]. Upregulation of genes encoding efflux pumps in response to NP exposure has been observed in clinically relevant bacteria. For instance, transcriptomic studies carried out by different laboratories proved that P. aeruginosa PAO1 overexpressed genes encoding resistance-nodulation-cell division (RND) pumps and other metal efflux systems when exposed to sublethal concentrations of $\mathrm{CuO}$ NPs [12] and cadmium quantum dots (Cd-QDs) [56]. Similarly, Ag-NPs were shown to induce the expression of genes encoding copper $(\operatorname{cop} A)$ and copper/silver efflux systems (cus $A)$ in $E$. coli as well $[8,61]$. Importantly, in addition to metal ions, RND efflux systems can expel antibiotics, and thus may confer resistance to both NPs and antibiotics. As it will be discussed later, the widespread use of Ag-NPs or Cu-NPs is raising concerns about potential co-selection of metal and antibiotic resistance $[27,62,63]$.

Furthermore, besides restricting the concentration of metal ions in the cytosol, a number of authors have proposed that bacteria could resist NPs by upregulating their antioxidant mechanisms as well [51]. Indeed, overexpression of genes encoding ROS scavenging systems have been demonstrated in E. coli, B. subtilis, and P. aeruginosa PAO1 exposed to Ag-NPs, $\mathrm{Al}_{2} \mathrm{O}_{3}-\mathrm{NPs}$, and $\mathrm{Cd}-\mathrm{QD}$, respectively $[56,57,64]$, and have been correlated with a better capacity to tolerate prolonged exposure to Ag-NPs [52]. Furthermore, recent work carried out by Valentin and collaborators [14] reported that Ag-NP resistance evolved in $S$. aureus was associated with mutations in genes involved in nucleotide synthesis and oxidative stress defenses.

While individual cells use their genetically encoded defense mechanisms to withstand NP toxicity, bacteria may also benefit from the additional protection conferred by collective responses as stated above. In addition to single or multispecies biofilms, bacteria can also form microbial aggregates with other microorganisms that allow them to withstand NP toxicity and other environmental stresses [54,65]. These aggregates consist of a consortia of microorganisms (such as protists, archaea, or fungi) that are embedded within a selfproduced extracellular polymeric substance (EPS) composed of polysaccharides, DNA, or peptides. Biofilms and microbial aggregates offer protection towards NPs in multiple ways. The EPS that forms the aggregate matrix acts as a physical barrier that hinders 
NP penetration and traps them at the periphery, thus reducing bacteria exposure $[20,66]$, or even modifying the properties of NPs, diminishing their reactivity and their antimicrobial effect $[54,66]$ (Figure 1B). Furthermore, limiting the penetration of NPs may allow bacteria in the interior of the aggregate to sense sub-lethal concentrations and develop an adaptive response that indeed increases NP resistance and enhances biofilm growth [67]. This phenomenon is called hormesis, and it is defined as a process in which exposure to a low dose of a chemical that is deleterious at high doses induces an adaptive beneficial effect on the cell [68]. Hormesis has been observed in different bacteria exposed to some antibiotics and metallic NPs. For example, sub-lethal doses of ZnO-NPs and Ag-NPs were found to promote growth of P. putida and P. aeruginosa biofilms, respectively, by inducing the expression of quorum sensing and LPS biosynthesis genes as well as the release of signal molecules by bacteria $[67,69]$. Similarly, S. oneidensis MR-1 was reported to increase the production of EPS when exposed to $\mathrm{Cu}$-doped $\mathrm{TiO}_{2}-\mathrm{NPs}$ [70].

\section{Arming the Enemy: Metallic NPs May Act as Pressure That Co-Selects for Antibiotic Resistance Genes}

It has been established that heavy metal exposure enhances the tolerance of bacteria to antibiotics [71-73], and that antibiotic-resistant bacteria are abundant in metal-polluted sites [74,75]. Importantly, field studies have described that long-term metal contamination co-selects for antibiotic-resistant genes (ARGs) and metal-resistant genes in different environments such as wastewater treatment plants [21,76], farms [77], and agriculture soils [78,79]. Furthermore, experimental evidence gathered over the last few years suggests that metallic NPs might facilitate the spread of antibiotic resistance between bacteria through co-selection and horizontal gene transference (HGT) of ARGs as well [62,80-82]. Hence, given the increasing use of NPs, concern is increasing as prolonged exposure of bacteria to sublethal levels of NPs could act as selective pressure that may accelerate the spread of antibiotic resistance in the environment.

Efforts are now directed at understanding the molecular basis by which NPs could promote the spread of antibiotic resistance. On one hand, metallic NPs could indirectly select for ARGs due to a cross-resistance phenomenon, in which a mechanism initially evolved to tolerate NPs would confer resistance to some antibiotics as well. The upregulation of efflux pumps that can extrude metal ions and antibiotics represents the most conspicuous example of this [71]. The increased abundance of efflux pump genes in soil and water environments under NP exposure has been proven by several studies $[14,15,35,56,61,62]$. As stated above, some efflux pumps of the RND family are known to export antibiotics in P. aeruginosa [83]. On the other hand, metallic NPs could promote horizontal transference of ARGs between bacteria. Over the last years, several studies have found that exposure to sub-inhibitory levels of metallic NPs favors bacterial conjugation and transformation in laboratory cultures [80,82,84,85], natural environments [62,86], and human-made systems [87]. Different laboratories recently observed higher transformation frequency when bacteria were exposed to either $\mathrm{ZnO}-\mathrm{NP}$ [86] or $\mathrm{Al}_{2} \mathrm{O}_{3}-\mathrm{NPs}$ [88]. Furthermore, a pioneer study [80] reported that low concentrations of $\mathrm{Al}_{2} \mathrm{O}_{3}$-NPs (nanoalumina) (up to $5 \mathrm{mM}$ ) promoted conjugative transfer of the multi-resistance plasmid RP4 between E. coli and Salmonella enteritidis. Conjugation frequency increased by a factor of 200-fold under $\mathrm{Al}_{2} \mathrm{O}_{3}-\mathrm{NP}$ exposure compared to the unexposed control cultures. Remarkably, the authors did not find any effect on conjugation frequency when bacteria were exposed to the same concentration of bulk alumina, suggesting a NP-specific effect [80]. Likewise, several studies have described enhanced conjugation transfer of ARGs in bacteria exposed to subinhibitory concentrations of $\mathrm{Al}_{2} \mathrm{O}_{3}-\mathrm{NPs}, \mathrm{ZnO}-\mathrm{NPs}, \mathrm{TiO}_{2}$-NPs, and $\mathrm{CuO}-\mathrm{NPs}$, whereas bulk or ionic $\mathrm{CuO}, \mathrm{Al}_{2} \mathrm{O}_{3}$, and $\mathrm{TiO}_{2}$ did not $[80,84-86,89]$.

Enhancement of HGT by NPs has also been described in "natural environments" as well. Recently, Qi and coworkers reported that rare earth oxide NPs $\left(\mathrm{La}_{2} \mathrm{O}_{3}, \mathrm{Nd}_{2} \mathrm{O}_{3}\right.$, and $\mathrm{Gd}_{2} \mathrm{O}_{3}$ NPs) enriched the abundance of ARGs in NP-amended soils, and that this was accompanied by enhanced tetracycline resistance in the microbial community [82]. The enhanced antibiotic resistance was detected 7 days after soil exposure to NPs and 
persisted over the whole course of the experiment (60 days). By applying high-capacity quantitative PCR the authors detected a significant increase in the abundance of $24 \%$ of the identified ARGs in NP-amended soils when compared to control soils. ARGs were differentially enriched under NP exposure and targeted all major classes of antibiotics [82]. Interestingly, these authors reported a positive correlation between enriched ARGs and the abundance of mobile genetic elements in the NP-amended soils, supporting the hypothesis that NPs might promote the ARG spread through HGT. Although not fully understood yet, the underlying mechanisms appear to involve membrane damage caused by NP-generated ROS and changes in the expression of genes regulating conjugation and transformation. It has been proposed that ROS generated by NPs would lead to both membrane and DNA damage. Indeed, membrane damage and an increased number of conjugative junctions have been observed by transmission electron microscopy (TEM) in E. coli and P. putida cells exposed to AgO-NPs [81], $\mathrm{Al}_{2} \mathrm{O}_{3}-\mathrm{NPs}$ [80], or CuO-NPs [89]. On one hand, membrane damage could favor DNA uptake by impairing the membrane barrier. This has been evidenced by different experimental approaches such as flow cytometry, RNAseq, and proteome analysis of conjugating bacteria exposed to CuO-NPs [89] or Ag-NPs [81]. On the other hand, damaged DNA would trigger the SOS response, which in turn might promote HGT by different mechanisms [90]. First, it has been recently proposed that $\operatorname{Rec} A$ overexpression during SOS response might favor recombination of single-stranded DNA with the recipient cell's DNA [91]. Additionally, RNAseq analysis of NP-exposed cells revealed upregulation of genes encoding the conjugative machinery (such as $\operatorname{tr} b B p, \operatorname{trf} A p$ ) and the SOS response, as well as suppression of genes that repress RP4 conjugation (kor $A$, $k o r B$, and $\operatorname{trb} A$ ) [80]. However, how this occurs has not been elucidated yet. Different studies have shown that sublethal concentrations of ROS-generating antibiotics and biocides promote conjugation via the SOS-response $[81,92,93]$. Accordingly, the conjugative transfer was found to decrease in the presence of ROS scavengers, supporting the role of ROS in this process [81,89]. Moreover, ROS generation in mating bacteria has been observed with ROS-specific fluorescent dyes, RNAseq, and proteome analysis. For instance, the transcriptomic profile of E. coli K12 MG1655 exposed to ZnO-NPs evidenced overexpression of oxidative stress-related genes $(\operatorname{soxS}, \operatorname{sox} R, \operatorname{oxy} R, \operatorname{ahp} C)$ and $\mathrm{SOS}$ response genes $(\mathrm{rec} X$, $s b m C, s s b, a d a)$ [94]. Similar results were described in E. coli and P. putida exposed to CuO NPs [89].

Lastly, it has been recently reported that NP exposure may contribute to antibiotic resistance by inducing mutations conferring antibiotic resistance. For instance, wholegenome sequencing carried out by Zhang and coworkers [94] found that nanoalumina and $\mathrm{ZnO}-\mathrm{NPs}$ induced mutations in gyrA and soxR genes that were associated with resistance to ciprofloxacin and chloramphenicol in E. coli. Remarkably, the resistant mutant strains displayed stable resistance to multiple antibiotics. The authors proposed that ROS generated by those NPs led to oxidative DNA damage that in turn triggered the SOS response and error-prone DNA polymerase, resulting in increased mutation rates.

\section{Strategies to Overcome Bacterial Resistance towards Metallic Nanoparticles}

Although a growing body of research has shown that bacteria can readily evolve resistance towards metallic NPs $[13,15,95]$, the genetic basis of NP resistance remains poorly understood. Recent studies reported that NP resistance might evolve through few mutations or without any significant genetic changes in different bacterial species. Graves and collaborators detected few genetic changes in AgNP-resistant isolates of E. coli $\mathrm{K}-12$ obtained in laboratory evolution experiments, although the contribution of these mutations to NP resistance has not been investigated yet [15]. In addition, Dong and coworkers reported that mutations in AgNP-resistant populations were mainly associated with the cell surface and two component systems [95]. Recently, Panacek and collaborators showed that three strains of E. coli and P. aeruginosa evolved Ag-NP resistance by overproducing flagellin, the main flagella protein, to facilitate NP aggregation and immobilization outside cells [13]. Remarkably, while this resistance mechanism was stable over many 
generations, the authors did not find any mutations in coding sequences in the genomes of the AgNP-resistant isolates. Importantly, the study led by Panacek suggests that the lack of genetic basis of some NP resistance mechanisms could be exploited to counteract bacterial resistance. Indeed, in their pioneer study, the authors were able to overcome Ag-NP resistance in E. coli by adding inhibitors of flagellin production such as pomegranate rind extract, [13], paving the way for the use of silver nanoparticles as effective antibacterial agents. Nevertheless, whereas metallic NPs do clearly exhibit tunable features that make them promising antibacterial agents against biofilms and antibiotic-resistant bacteria, further investigation is needed. Caution in the use of NPs for antibacterial purposes is highly recommended, as research published over the last years has proven that continuous exposure to metallic NPs could lead to the development of resistance mechanisms and might contribute to the spread of antibiotic resistances as well.

Author Contributions: Conception and design, F.A., Á.M.; literature review, F.A., Á.M., S.D., A.M.G., J.C.G.; writing—original draft preparation, F.A.; writing—critical revision and editing, Á.M., S.D., A.M.-G. and J.C.G.; funding acquisition: J.C.G. All authors have read and agreed to the published version of the manuscript.

Funding: This article was funded by the Spanish Ministry of Economy and Competitiveness, grant number CGL2016-75494-R awarded to J.C.G.

Institutional Review Board Statement: Not applicable.

Informed Consent Statement: Not applicable.

Data Availability Statement: Not applicable.

Conflicts of Interest: The authors declare no conflict of interest.

\section{References}

1. Davis, M.; Whittaker, A.; Lindgren, M.; Djerf-Pierre, M.; Manderson, L.; Flowers, P. Understanding media publics and the antimicrobial resistance crisis. Glob. Public Health 2018, 13, 1158-1168. [CrossRef]

2. Holmes, A.H.; Moore, L.S.; Sundsfjord, A.; Steinbakk, M.; Regmi, S.; Karkey, A.; Guerin, P.J.; Piddock, L.J. Understanding the mechanisms and drivers of antimicrobial resistance. Lancet 2016, 387, 176-187. [CrossRef]

3. Blair, J.M.; Webber, M.A.; Baylay, A.J.; Ogbolu, D.O.; Piddock, L.J. Molecular mechanisms of antibiotic resistance. Nat. Rev. Microbiol. 2015, 13, 42-51. [CrossRef]

4. Davies, D. Understanding biofilm resistance to antibacterial agents. Nat. Rev. Drug Discov. 2003, 2, 114-122. [CrossRef]

5. Makabenta, J.M.V.; Nabawy, A.; Li, C.H.; Schmidt-Malan, S.; Patel, R.; Rotello, V.M. Nanomaterial-based therapeutics for antibiotic-resistant bacterial infections. Nat. Rev. Microbiol. 2021, 19, 23-36. [CrossRef]

6. Gupta, A.; Mumtaz, S.; Li, C.H.; Hussain, I.; Rotello, V.M. Combatting antibiotic-resistant bacteria using nanomaterials. Chem. Soc. Rev. 2019, 48, 415-427. [CrossRef]

7. Malhotra, B.; Keshwani, A.; Kharkwal, H. Antimicrobial food packaging: Potential and pitfalls. Front. Microbiol. 2015,6 , 611. [CrossRef]

8. Baptista, P.V.; McCusker, M.P.; Carvalho, A.; Ferreira, D.A.; Mohan, N.M.; Martins, M.; Fernandes, A.R. Nano-Strategies to Fight Multidrug Resistant Bacteria-"A Battle of the Titans". Front. Microbiol. 2018, 9, 1441. [CrossRef]

9. Hoseinnejad, M.; Jafari, S.M.; Katouzian, I. Inorganic and metal nanoparticles and their antimicrobial activity in food packaging applications. Crit. Rev. Microbiol 2018, 44, 161-181. [CrossRef]

10. Beisl, S.; Monteiro, S.; Santos, R.; Figueiredo, A.S.; Sanchez-Loredo, M.G.; Lemos, M.A.; Lemos, F.; Minhalma, M.; de Pinho, M.N. Synthesis and bactericide activity of nanofiltration composite membrane-Cellulose acetate/silver nanoparticles and cellulose acetate/silver ion exchanged zeolites. Water Res. 2019, 149, 225-231. [CrossRef]

11. Fernandez-Moure, J.S.; Evangelopoulos, M.; Colvill, K.; Van Eps, J.L.; Tasciotti, E. Nanoantibiotics: A new paradigm for the treatment of surgical infection. Nanomedicine 2017, 12, 1319-1334. [CrossRef]

12. Guo, J.; Gao, S.H.; Lu, J.; Bond, P.L.; Verstraete, W.; Yuan, Z. Copper Oxide Nanoparticles Induce Lysogenic Bacteriophage and Metal-Resistance Genes in Pseudomonas aeruginosa PAO1. ACS Appl Mater. Interfaces 2017, 9, 22298-22307. [CrossRef]

13. Panacek, A.; Kvitek, L.; Smekalova, M.; Vecerova, R.; Kolar, M.; Roderova, M.; Dycka, F.; Sebela, M.; Prucek, R.; Tomanec, O.; et al Bacterial resistance to silver nanoparticles and how to overcome it. Nat. Nanotechnol. 2018, 13, 65-71. [CrossRef]

14. Valentin, E.; Bottomley, A.L.; Chilambi, G.S.; Harry, E.J.; Amal, R.; Sotiriou, G.A.; Rice, S.A.; Gunawan, C. Heritable nanosilver resistance in priority pathogen: A unique genetic adaptation and comparison with ionic silver and antibiotics. Nanoscale 2020, 12, 2384-2392. [CrossRef] 
15. Graves, J.L., Jr.; Tajkarimi, M.; Cunningham, Q.; Campbell, A.; Nonga, H.; Harrison, S.H.; Barrick, J.E. Rapid evolution of silver nanoparticle resistance in Escherichia coli. Front. Genet. 2015, 6, 42. [CrossRef]

16. Alexander, J.W. History of the medical use of silver. Surg. Infect. 2009, 10, 289-292. [CrossRef]

17. Li, X.; Robinson, S.M.; Gupta, A.; Saha, K.; Jiang, Z.; Moyano, D.F.; Sahar, A.; Riley, M.A.; Rotello, V.M. Functional gold nanoparticles as potent antimicrobial agents against multi-drug-resistant bacteria. ACS Nano 2014, 8, 10682-10686. [CrossRef]

18. Sirelkhatim, A.; Mahmud, S.; Seeni, A.; Kaus, N.H.M.; Ann, L.C.; Bakhori, S.K.M.; Hasan, H.; Mohamad, D. Review on Zinc Oxide Nanoparticles: Antibacterial Activity and Toxicity Mechanism. Nanomicro. Lett. 2015, 7, 219-242. [CrossRef]

19. Sotiriou, G.A.; Pratsinis, S.E. Antibacterial activity of nanosilver ions and particles. Environ. Sci. Technol. 2010, 44, 5649-5654. [CrossRef]

20. Peulen, T.O.; Wilkinson, K.J. Diffusion of nanoparticles in a biofilm. Environ. Sci. Technol. 2011, 45, 3367-3373. [CrossRef]

21. Huang, T.; Holden, J.A.; Heath, D.E.; O'Brien-Simpson, N.M.; O'Connor, A.J. Engineering highly effective antimicrobial selenium nanoparticles through control of particle size. Nanoscale 2019, 11, 14937-14951. [CrossRef]

22. Ivask, A.; Kurvet, I.; Kasemets, K.; Blinova, I.; Aruoja, V.; Suppi, S.; Vija, H.; Kakinen, A.; Titma, T.; Heinlaan, M.; et al. Sizedependent toxicity of silver nanoparticles to bacteria, yeast, algae, crustaceans and mammalian cells in vitro. PLoS ONE 2014, 9, e102108. [CrossRef]

23. Hayden, S.C.; Zhao, G.; Saha, K.; Phillips, R.L.; Li, X.; Miranda, O.R.; Rotello, V.M.; El-Sayed, M.A.; Schmidt-Krey, I.; Bunz, U.H.F. Aggregation and Interaction of Cationic Nanoparticles on Bacterial Surfaces. J. Am. Chem. Soc. 2012, 134, 6920-6923. [CrossRef]

24. Simon-Deckers, A.; Loo, S.; Mayne-L'hermite, M.; Herlin-Boime, N.; Menguy, N.; Reynaud, C.; Gouget, B.; Carrière, M. Size-, Composition- and Shape-Dependent Toxicological Impact of Metal Oxide Nanoparticles and Carbon Nanotubes toward Bacteria. Environ. Sci. Technol. 2009, 43, 8423-8429. [CrossRef]

25. Mukha Iu, P.; Eremenko, A.M.; Smirnova, N.P.; Mikhienkova, A.I.; Korchak, G.I.; Gorchev, V.F.; Chunikhin, A. Antimicrobial activity of stable silver nanoparticles of a certain size. Prikl. Biokhim. Mikrobiol. 2013, 49, 215-223. [CrossRef]

26. Wu, J.; Li, F.; Hu, X.; Lu, J.; Sun, X.; Gao, J.; Ling, D. Responsive Assembly of Silver Nanoclusters with a Biofilm Locally Amplified Bactericidal Effect to Enhance Treatments against Multi-Drug-Resistant Bacterial Infections. ACS Cent. Sci. 2019, 5, 1366-1376. [CrossRef]

27. Metch, J.W.; Burrows, N.D.; Murphy, C.J.; Pruden, A.; Vikesland, P.J. Metagenomic analysis of microbial communities yields insight into impacts of nanoparticle design. Nat. Nanotechnol. 2018, 13, 253-259. [CrossRef]

28. Pal, S.; Tak, Y.K.; Song, J.M. Does the antibacterial activity of silver nanoparticles depend on the shape of the nanoparticle? A study of the Gram-negative bacterium Escherichia coli. Appl. Environ. Microbiol. 2007, 73, 1712-1720. [CrossRef]

29. Tian, X.; Jiang, X.; Welch, C.; Croley, T.R.; Wong, T.Y.; Chen, C.; Fan, S.; Chong, Y.; Li, R.; Ge, C.; et al. Bactericidal Effects of Silver Nanoparticles on Lactobacilli and the Underlying Mechanism. ACS Appl. Mater. Interfaces 2018, 10, 8443-8450. [CrossRef]

30. Natan, M.; Banin, E. From Nano to Micro: Using nanotechnology to combat microorganisms and their multidrug resistance. Fems Microbiol. Rev. 2017, 41, 302-322. [CrossRef]

31. Suresh, A.K.; Pelletier, D.A.; Wang, W.; Moon, J.W.; Gu, B.; Mortensen, N.P.; Allison, D.P.; Joy, D.C.; Phelps, T.J.; Doktycz, M.J. Silver nanocrystallites: Biofabrication using Shewanella oneidensis, and an evaluation of their comparative toxicity on gram-negative and gram-positive bacteria. Environ. Sci. Technol. 2010, 44, 5210-5215. [CrossRef]

32. Ivask, A.; Elbadawy, A.; Kaweeteerawat, C.; Boren, D.; Fischer, H.; Ji, Z.; Chang, C.H.; Liu, R.; Tolaymat, T.; Telesca, D.; et al. Toxicity mechanisms in Escherichia coli vary for silver nanoparticles and differ from ionic silver. ACS Nano 2014, 8, 374-386. [CrossRef]

33. Moore, J.D.; Avellan, A.; Noack, C.W.; Guo, Y.; Lowry, G.V.; Gregory, K.B. Time-dependent bacterial transcriptional response to $\mathrm{CuO}$ nanoparticles differs from that of $\mathrm{Cu} 2+$ and provides insights into $\mathrm{CuO}$ nanoparticle toxicity mechanisms. Environ. Sci. Nano 2017, 4, 2321-2335. [CrossRef]

34. Hajipour, M.J.; Fromm, K.M.; Ashkarran, A.A.; Jimenez de Aberasturi, D.; de Larramendi, I.R.; Rojo, T.; Serpooshan, V.; Parak, W.J.; Mahmoudi, M. Antibacterial properties of nanoparticles. Trends Biotechnol. 2012, 30, 499-511. [CrossRef]

35. Kaweeteerawat, C.; Chang, C.H.; Roy, K.R.; Liu, R.; Li, R.; Toso, D.; Fischer, H.; Ivask, A.; Ji, Z.; Zink, J.I.; et al. Cu Nanoparticles Have Different Impacts in Escherichia coli and Lactobacillus brevis than Their Microsized and Ionic Analogues. ACS Nano 2015, 9, 7215-7225. [CrossRef]

36. Chatterjee, A.K.; Chakraborty, R.; Basu, T. Mechanism of antibacterial activity of copper nanoparticles. Nanotechnology 2014, 25, 135101. [CrossRef]

37. Singh, P.; Garg, A.; Pandit, S.; Mokkapati, V.; Mijakovic, I. Antimicrobial Effects of Biogenic Nanoparticles. Nanomater 2018, 8. [CrossRef]

38. Dakal, T.C.; Kumar, A.; Majumdar, R.S.; Yadav, V. Mechanistic Basis of Antimicrobial Actions of Silver Nanoparticles. Front. Microbiol. 2016, 7, 1831. [CrossRef]

39. Bondarenko, O.M.; Sihtmae, M.; Kuzmiciova, J.; Rageliene, L.; Kahru, A.; Daugelavicius, R. Plasma membrane is the target of rapid antibacterial action of silver nanoparticles in Escherichia coli and Pseudomonas aeruginosa. Int. J. Nanomed. 2018, 13, 6779-6790. [CrossRef]

40. Stabryla, L.M.; Johnston, K.A.; Millstone, J.E.; Gilbertson, L.M. Emerging investigator series: it's not all about the ion: Support for particle-specific contributions to silver nanoparticle antimicrobial activity. Environ. Sci. Nano 2018, 5, 2047-2068. [CrossRef] 
41. Wang, L.; Hu, C.; Shao, L. The antimicrobial activity of nanoparticles: Present situation and prospects for the future. Int. J. Nanomed. 2017, 12, 1227-1249. [CrossRef]

42. Dwivedi, S.; Wahab, R.; Khan, F.; Mishra, Y.K.; Musarrat, J.; Al-Khedhairy, A.A. Reactive oxygen species mediated bacterial biofilm inhibition via zinc oxide nanoparticles and their statistical determination. PLoS ONE 2014, 9, e111289. [CrossRef]

43. Slavin, Y.N.; Asnis, J.; Hafeli, U.O.; Bach, H. Metal nanoparticles: Understanding the mechanisms behind antibacterial activity. J. Nanobiotechnol. 2017, 15, 65. [CrossRef]

44. Su, Y.; Zheng, X.; Chen, Y.; Li, M.; Liu, K. Alteration of intracellular protein expressions as a key mechanism of the deterioration of bacterial denitrification caused by copper oxide nanoparticles. Sci. Rep. 2015, 5, 15824. [CrossRef]

45. Rai, M.K.; Deshmukh, S.D.; Ingle, A.P.; Gade, A.K. Silver nanoparticles: The powerful nanoweapon against multidrug-resistant bacteria. J. Appl. Microbiol. 2012, 112, 841-852. [CrossRef]

46. Finley, P.J.; Norton, R.; Austin, C.; Mitchell, A.; Zank, S.; Durham, P. Unprecedented Silver Resistance in Clinically Isolated Enterobacteriaceae: Major Implications for Burn and Wound Management. Antimicrob. Agents Chemother. 2015, 59, $4734-4741$. [CrossRef]

47. Vasileiadis, S.; Puglisi, E.; Trevisan, M.; Scheckel, K.G.; Langdon, K.A.; McLaughlin, M.J.; Lombi, E.; Donner, E. Changes in soil bacterial communities and diversity in response to long-term silver exposure. FEMS Microbiol. Ecol. 2015, 91. [CrossRef]

48. Saeb, A.T.M.; Al-Rubeaan, K.A.; Abouelhoda, M.; Selvaraju, M.; Tayeb, H.T. Genome sequencing and analysis of the first spontaneous Nanosilver resistant bacterium Proteus mirabilis strain SCDR1. Antimicrob. Resist. Infect. Control. 2017, 6, 119. [CrossRef]

49. Mitchell, S.L.; Hudson-Smith, N.V.; Cahill, M.S.; Reynolds, B.N.; Frand, S.D.; Green, C.M.; Wang, C.; Hang, M.N.; Hernandez, R.T.; Hamers, R.J.; et al. Chronic exposure to complex metal oxide nanoparticles elicits rapid resistance in Shewanella oneidensis MR-1. Chem. Sci. 2019, 10, 9768-9781. [CrossRef]

50. Zheng, H.; Ji, Z.; Roy, K.R.; Gao, M.; Pan, Y.; Cai, X.; Wang, L.; Li, W.; Chang, C.H.; Kaweeteerawat, C.; et al. Engineered Graphene Oxide Nanocomposite Capable of Preventing the Evolution of Antimicrobial Resistance. ACS Nano 2019, 13, 11488-11499. [CrossRef]

51. Nino-Martinez, N.; Salas Orozco, M.F.; Martinez-Castanon, G.A.; Torres Mendez, F.; Ruiz, F. Molecular Mechanisms of Bacterial Resistance to Metal and Metal Oxide Nanoparticles. Int. J. Mol. Sci. 2019, 20. [CrossRef]

52. Gunawan, C.; Teoh, W.Y.; Marquis, C.P.; Amal, R. Induced adaptation of Bacillus sp. to antimicrobial nanosilver. Small 2013, 9 , 3554-3560. [CrossRef]

53. Yuan, W.; Wei, Y.; Zhang, Y.; Riaz, L.; Yang, Q.; Wang, Q.; Wang, R. Resistance of multidrug resistant Escherichia coli to environmental nanoscale $\mathrm{TiO}_{2}$ and $\mathrm{ZnO}$. Sci. Total Environ. 2020, 761, 144303. [CrossRef]

54. Tang, J.; Wu, Y.; Esquivel-Elizondo, S.; Sorensen, S.J.; Rittmann, B.E. How Microbial Aggregates Protect against Nanoparticle Toxicity. Trends Biotechnol. 2018, 36, 1171-1182. [CrossRef]

55. Ellis, D.H.; Maurer-Gardner, E.I.; Sulentic, C.E.W.; Hussain, S.M. Silver nanoparticle antibacterial efficacy and resistance development in key bacterial species. Biomed. Phys. Eng. Express 2018, 5, 015013. [CrossRef]

56. Yang, Y.; Mathieu, J.M.; Chattopadhyay, S.; Miller, J.T.; Wu, T.; Shibata, T.; Guo, W.; Alvarez, P.J. Defense mechanisms of Pseudomonas aeruginosa PAO1 against quantum dots and their released heavy metals. ACS Nano 2012, 6, 6091-6098. [CrossRef]

57. Gou, N.; Onnis-Hayden, A.; Gu, A.Z. Mechanistic toxicity assessment of nanomaterials by whole-cell-array stress genes expression analysis. Environ. Sci. Technol. 2010, 44, 5964-5970. [CrossRef]

58. McQuillan, J.S.; Shaw, A.M. Differential gene regulation in the Ag nanoparticle and Ag(+)-induced silver stress response in Escherichia coli: A full transcriptomic profile. Nanotoxicology 2014, 8, 177-184. [CrossRef]

59. McQuillan, J.S.; Infante, H.G.; Stokes, E.; Shaw, A.M. Silver nanoparticle enhanced silver ion stress response in Escherichia coli K12. Nanotoxicology 2012, 6, 857-866. [CrossRef]

60. Radzig, M.A.; Nadtochenko, V.A.; Koksharova, O.A.; Kiwi, J.; Lipasova, V.A.; Khmel, I.A. Antibacterial effects of silver nanoparticles on gram-negative bacteria: Influence on the growth and biofilms formation, mechanisms of action. Colloids Surf. B Biointerfaces 2013, 102, 300-306. [CrossRef]

61. Faghihzadeh, F.; Anaya, N.M.; Astudillo-Castro, C.; Oyanedel-Craver, V. Kinetic, metabolic and macromolecular response of bacteria to chronic nanoparticle exposure in continuous culture. Environ. Sci. Nano 2018, 5, 1386-1396. [CrossRef]

62. Chen, Q.L.; Zhu, D.; An, X.L.; Ding, J.; Zhu, Y.G.; Cui, L. Does nano silver promote the selection of antibiotic resistance genes in soil and plant? Environ. Int. 2019, 128, 399-406. [CrossRef]

63. Gunawan, C.; Marquis, C.P.; Amal, R.; Sotiriou, G.A.; Rice, S.A.; Harry, E.J. Widespread and Indiscriminate Nanosilver Use: Genuine Potential for Microbial Resistance. ACS Nano 2017, 11, 3438-3445. [CrossRef]

64. Mu, D.; Yu, X.; Xu, Z.; Du, Z.; Chen, G. Physiological and transcriptomic analyses reveal mechanistic insight into the adaption of marine Bacillus subtilis C01 to alumina nanoparticles. Sci. Rep. 2016, 6, 29953. [CrossRef]

65. Sheng, Z.; Van Nostrand, J.D.; Zhou, J.; Liu, Y. The effects of silver nanoparticles on intact wastewater biofilms. Front. Microbiol. 2015, 6, 680. [CrossRef]

66. Wang, Q.; Kang, F.; Gao, Y.; Mao, X.; Hu, X. Sequestration of nanoparticles by an EPS matrix reduces the particle-specific bactericidal activity. Sci. Rep. 2016, 6, 21379. [CrossRef]

67. Ouyang, K.; Mortimer, M.; Holden, P.A.; Cai, P.; Wu, Y.; Gao, C.; Huang, Q. Towards a better understanding of Pseudomonas putida biofilm formation in the presence of ZnO nanoparticles (NPs): Role of NP concentration. Environ. Int. 2020, 137, 105485. [CrossRef]

68. Calabrese, E.J.; Baldwin, L.A. Toxicology rethinks its central belief. Nature 2003, 421, 691-692. [CrossRef] 
69. Yang, Y.; Alvarez, P.J.J. Sublethal Concentrations of Silver Nanoparticles Stimulate Biofilm Development. Environ. Sci. Technol. Lett. 2015, 2, 221-226. [CrossRef]

70. Wu, B.; Huang, R.; Sahu, M.; Feng, X.; Biswas, P.; Tang, Y.J. Bacterial responses to Cu-doped TiO(2) nanoparticles. Sci. Total Environ. 2010, 408, 1755-1758. [CrossRef]

71. Baker-Austin, C.; Wright, M.S.; Stepanauskas, R.; McArthur, J.V. Co-selection of antibiotic and metal resistance. Trends Microbiol. 2006, 14, 176-182. [CrossRef]

72. Cui, L.; Zhang, Y.J.; Huang, W.E.; Zhang, B.F.; Martin, F.L.; Li, J.Y.; Zhang, K.S.; Zhu, Y.G. Surface-Enhanced Raman Spectroscopy for Identification of Heavy Metal Arsenic(V)-Mediated Enhancing Effect on Antibiotic Resistance. Anal. Chem. 2016, 88, 3164-3170. [CrossRef]

73. Knapp, C.W.; Callan, A.C.; Aitken, B.; Shearn, R.; Koenders, A.; Hinwood, A. Relationship between antibiotic resistance genes and metals in residential soil samples from Western Australia. Environ. Sci. Pollut Res. Int. 2017, 24, 2484-2494. [CrossRef]

74. Berg, J.; Tom-Petersen, A.; Nybroe, O. Copper amendment of agricultural soil selects for bacterial antibiotic resistance in the field. Lett. Appl. Microbiol. 2005, 40, 146-151. [CrossRef]

75. Nguyen, C.C.; Hugie, C.N.; Kile, M.L.; Navab-Daneshmand, T. Association between heavy metals and antibiotic-resistant human pathogens in environmental reservoirs: A review. Front. Environ. Sci. Eng. 2019, 13, 46. [CrossRef]

76. Di Cesare, A.; Eckert, E.M.; D’Urso, S.; Bertoni, R.; Gillan, D.C.; Wattiez, R.; Corno, G. Co-occurrence of integrase 1, antibiotic and heavy metal resistance genes in municipal wastewater treatment plants. Water Res. 2016, 94, 208-214. [CrossRef]

77. Zhou, B.; Wang, C.; Zhao, Q.; Wang, Y.; Huo, M.; Wang, J.; Wang, S. Prevalence and dissemination of antibiotic resistance genes and coselection of heavy metals in Chinese dairy farms. J. Hazard. Mater. 2016, 320, 10-17. [CrossRef]

78. Hu, H.W.; Wang, J.T.; Li, J.; Li, J.J.; Ma, Y.B.; Chen, D.; He, J.Z. Field-based evidence for copper contamination induced changes of antibiotic resistance in agricultural soils. Environ. Microbiol. 2016, 18, 3896-3909. [CrossRef]

79. Hu, H.W.; Wang, J.T.; Li, J.; Shi, X.Z.; Ma, Y.B.; Chen, D.; He, J.Z. Long-Term Nickel Contamination Increases the Occurrence of Antibiotic Resistance Genes in Agricultural Soils. Environ. Sci. Technol. 2017, 51, 790-800. [CrossRef]

80. Qiu, Z.; Yu, Y.; Chen, Z.; Jin, M.; Yang, D.; Zhao, Z.; Wang, J.; Shen, Z.; Wang, X.; Qian, D.; et al. Nanoalumina promotes the horizontal transfer of multiresistance genes mediated by plasmids across genera. Proc. Natl. Acad. Sci. USA 2012, 109, 4944-4949. [CrossRef]

81. Liu, X.; Tang, J.; Song, B.; Zhen, M.; Wang, L.; Giesy, J.P. Exposure to $\mathrm{Al}_{2} \mathrm{O}_{3}$ nanoparticles facilitates conjugative transfer of antibiotic resistance genes from Escherichia coli to Streptomyces. Nanotoxicology 2019, 13, 1422-1436. [CrossRef]

82. Qi, L.; Ge, Y.; Xia, T.; He, J.-Z.; Shen, C.; Wang, J.; Liu, Y.-J. Rare earth oxide nanoparticles promote soil microbial antibiotic resistance by selectively enriching antibiotic resistance genes. Environ. Sci. Nano 2019, 6, 456-466. [CrossRef]

83. Cunrath, O.; Meinel, D.M.; Maturana, P.; Fanous, J.; Buyck, J.M.; Saint Auguste, P.; Seth-Smith, H.M.B.; Korner, J.; Dehio, C.; Trebosc, V.; et al. Quantitative contribution of efflux to multi-drug resistance of clinical Escherichia coli and Pseudomonas aeruginosa strains. EBioMedicine 2019, 41, 479-487. [CrossRef]

84. Ding, C.; Jin, M.; Ma, J.; Chen, Z.; Shen, Z.; Yang, D.; Shi, D.; Liu, W.; Kang, M.; Wang, J.; et al. Nano- $\mathrm{Al}_{2} \mathrm{O}_{3}$ can mediate transduction-like transformation of antibiotic resistance genes in water. J. Hazard. Mater. 2020. [CrossRef]

85. Qiu, Z.; Shen, Z.; Qian, D.; Jin, M.; Yang, D.; Wang, J.; Zhang, B.; Yang, Z.; Chen, Z.; Wang, X.; et al. Effects of nano-TiO2 on antibiotic resistance transfer mediated by RP4 plasmid. Nanotoxicology 2015, 9, 895-904. [CrossRef]

86. Wang, X.; Yang, F.; Zhao, J.; Xu, Y.; Mao, D.; Zhu, X.; Luo, Y.; Alvarez, P.J.J. Bacterial exposure to ZnO nanoparticles facilitates horizontal transfer of antibiotic resistance genes. NanoImpact 2018, 10, 61-67. [CrossRef]

87. Huang, H.; Chen, Y.; Yang, S.; Zheng, X. CuO and ZnO nanoparticles drive the propagation of antibiotic resistance genes during sludge anaerobic digestion: Possible role of stimulated signal transduction. Environ. Sci. Nano 2019, 6, 528-539. [CrossRef]

88. Ding, C.; Pan, J.; Jin, M.; Yang, D.; Shen, Z.; Wang, J.; Zhang, B.; Liu, W.; Fu, J.; Guo, X.; et al. Enhanced uptake of antibiotic resistance genes in the presence of nanoalumina. Nanotoxicology 2016, 10, 1051-1060. [CrossRef]

89. Zhang, S.; Wang, Y.; Song, H.; Lu, J.; Yuan, Z.; Guo, J. Copper nanoparticles and copper ions promote horizontal transfer of plasmid-mediated multi-antibiotic resistance genes across bacterial genera. Environ. Int. 2019, 129, 478-487. [CrossRef]

90. Beaber, J.W.; Hochhut, B.; Waldor, M.K. SOS response promotes horizontal dissemination of antibiotic resistance genes. Nature 2004, 427, 72-74. [CrossRef]

91. Crane, J.K.; Cheema, M.B.; Olyer, M.A.; Sutton, M.D. Zinc Blockade of SOS Response Inhibits Horizontal Transfer of Antibiotic Resistance Genes in Enteric Bacteria. Front. Cell Infect. Microbiol. 2018, 8, 410. [CrossRef]

92. Baharoglu, Z.; Mazel, D. SOS, the formidable strategy of bacteria against aggressions. Fems Microbiol. Rev. 2014, 38, 1126-1145. [CrossRef]

93. Maiques, E.; Ubeda, C.; Campoy, S.; Salvador, N.; Lasa, I.; Novick, R.P.; Barbe, J.; Penades, J.R. beta-lactam antibiotics induce the SOS response and horizontal transfer of virulence factors in Staphylococcus aureus. J. Bacteriol. 2006, 188, 2726-2729. [CrossRef]

94. Zhang, Y.; Gu, A.Z.; Xie, S.; Li, X.; Cen, T.; Li, D.; Chen, J. Nano-metal oxides induce antimicrobial resistance via radical-mediated mutagenesis. Environ. Int. 2018, 121, 1162-1171. [CrossRef]

95. Dong, F.; Quevedo, A.C.; Wang, X.; Valsami-Jones, E.; Kreft, J.-U. Experimental Evolution of Pseudomonas putida under Silver Ion versus Nanoparticle Stress. bioRxiv 2020. [CrossRef] 